\title{
Adipose-derived mesenchymal stem cells exhibit tumor tropism and promote tumorsphere formation of breast cancer cells
}

\author{
YANQING CHEN", YUNFAN HE ${ }^{*}$, XUECEN WANG, FENG LU and JIANHUA GAO \\ Department of Plastic and Cosmetic Surgery, Nanfang Hospital, Southern Medical University, \\ Guangzhou, Guangdong 510515, P.R. China
}

Received June 21, 2018; Accepted January 25, 2019

DOI: 10.3892/or.2019.7018

\begin{abstract}
Mesenchymal stem cells reportedly have a marked effect on tumor growth or suppression. However, it remains uncertain whether adipose-derived mesenchymal stem cells (ADSCs) from grafted fat can contribute to breast cancer growth and recurrence. In the present study, interactions between ADSCs and MCF-7 breast cancer cells were evaluated in a Matrigel co-culture system and in an in vivo nude mouse model. Results suggested that MCF-7 cells exerted tumor tropism effects on ADSCs and this may be regulated by chemokines, such as the macrophage inflammatory protein (MIP)-1 $\delta$ and MIP-3 $\alpha$. Additionally, ADSCs significantly induced tumorsphere formation in vitro and promoted tumorigenicity in vivo. RT-qPCR analysis indicated that tumorsphere formation by MCF-7 cells was associated with the induction of stem-like properties, which was mediated by epithelialmesenchymal transition. Together, the present findings indicated that ADSCs exhibit tropism and induce tumorsphere formation of MCF-7 cells.
\end{abstract}

\section{Introduction}

Breast cancer remains one of the most frequent malignancies in women, accounting for $\sim 350,000$ annual mortalities in recent years worldwide $(1,2)$. Surgical treatment is currently the preferred option for almost all types of breast cancer. However, surgical incision procedures lead to the loss of breast volume and distortion of shape, and follow-up radiation

Correspondence to: Dr Jianhua Gao or Dr Feng Lu, Department of Plastic and Cosmetic Surgery, Nanfang Hospital, Southern Medical University, 1838 Guangzhou North Road, Guangzhou, Guangdong 510515, P.R. China

E-mail: gaopsnf@163.com

E-mail: doctorlufeng@hotmail.com

*Contributed equally

Key words: adipose-derived mesenchymal stem cells, tumor tropism, tumorsphere formation, epithelial-mesenchymal transition, breast cancer therapy often results in breast tissue fibrosis and poor wound healing $(3,4)$. Among the plastic surgery techniques currently available to reconstruct the breast, fat grafting is gaining major interest given its ease to harvest, low morbidity and capacity to improve the tissue quality, particularly in breast-conserving surgery (5-9). However, the possibility that breast cancer cells may still reside in patients with breast cancer after the surgical treatment cannot be completely excluded.

Adipose tissue is a multifunctional organ mainly consisted of mature adipocytes and the adipose mesenchymal stromal cells (MSCs)/stromal vascular fraction. Adipose MSCs are heterogeneous and contain several populations, including adipose-derived stem cells (ADSCs), endothelial progenitor cells, pre-adipocytes, lymphocytes, mast cells, pericytes, and adipose-resident macrophages $(10,11)$. Transplantation of adipose tissue, consisting of ADSCs that are metabolically active and secrete various cytokines, does not simply behave as an inert filler but it tends to influence the cancer microenvironment $(12,13)$. Hence, whether fat grafting can be applied to patients following breast cancer surgery is still a controversial issue.

It is widely recognized that multipotent ADSCs with their regenerative features, such as pro-angiogenic, anti-apoptotic, pro-proliferative and multipotent differentiation characteristics, within the transferred fat mainly contribute to the restorative and reconstructive qualities of autologous fat grafting (14-16). Unfortunately, these regenerative features are also assumed to be associated with tumor initiation and metastasis, causing safety concerns in clinical utilization. Notably, the majority of studies investigate the interaction between ADSCs and breast cancer cells and are performed in a two-dimensional (2D) context in vitro (17-20), which does not fully recapitulate the in vivo condition. Hence, an in vitro 3D culture system was established and applied an in vivo animal model to investigate the interaction between ADSCs and MCF-7 breast cancer cells in tumor development in the present study, mainly focusing on the tropism of ADSCs towards the breast cancer cells and the potential mechanism of ADSCs on promoting MCF-7 cells progression.

\section{Materials and methods}

Ethics approval. All procedures performed in the present study involving human participants were approved by the Southern 
Medical University Institutional Review Board (Guangzhou, China) and the patient provided written informed consent to donate remaining tissues after liposuction. All procedures performed involving animal experiments were approved by the Nanfang Hospital animal ethic committee (permit no. NFYY201679) and was conducted in accordance with the ethical standards of the National Health and Medical Research Council China.

Cell preparation and identification. Human ADSCs were isolated from abdominal liposuction aspirates of a 28 -year-old female patient during an abdominoplasty procedure with informed consent under approval from the Southern Medical University Institutional Review Board. Briefly, fat aspirate was washed with PBS, centrifuged at $800 \mathrm{xg}$ at $25^{\circ} \mathrm{C}$ for $5 \mathrm{~min}$ and digested with $0.1 \%$ collagenase at $37^{\circ} \mathrm{C}$ for $2 \mathrm{~h}$. The dispersed material was centrifuged $\left(170 \mathrm{x} \mathrm{g} ; 25^{\circ} \mathrm{C}\right)$ for $5 \mathrm{~min}$, and the pellet was resuspended in Dulbecco's modified Eagle's medium (DMEM; Invitrogen; Thermo Fisher Scientific, Inc., Waltham, MA, USA) with $10 \%$ fetal bovine serum (FBS; Gibco; Thermo Fisher Scientific, Inc.), $100 \mathrm{U} / \mathrm{ml}$ penicillin and $100 \mu \mathrm{g} / \mathrm{ml}$ streptomycin, and seeded in flasks. Next day, non-adherent cells were removed, and the remaining cells were cultured until $80 \%$ confluency. Passage 3 ADSCs were used in the following experiments. For the senescence evaluation of used cells, passage 3 ADSCs were further subjected to replicative senescence experiments. For a control culture, the same senescence experiments were conducted on ADSCs at passage 10.

MCF-7 cells were obtained from the Research Laboratory Collaboration Alliance of Nan Fang Hospital (Guangzhou, China). All cells used in the present study were maintained in DMEM supplemented with $10 \%$ FBS, $100 \mathrm{U} / \mathrm{ml}$ penicillin and $100 \mu \mathrm{g} / \mathrm{ml}$ streptomycin, in a humidified (85\%) atmosphere with $5 \% \mathrm{CO}_{2}$ at $37^{\circ} \mathrm{C}$.

To induce multilineage differentiation, ADSCs were cultured in adipogenic, osteogenic, and chondrogenic medium as previously described (21). Fat, bone and cartilage cells differentiated from ADSCs were identified by staining with Oil Red $\mathrm{O}\left(15 \mathrm{~min}\right.$ at $\left.25^{\circ} \mathrm{C}\right)$, Alizarin red $\left(5 \mathrm{~min}\right.$ at $\left.25^{\circ} \mathrm{C}\right)$ or Alcian blue $\left(30 \mathrm{~min}\right.$ at $25^{\circ} \mathrm{C}$ ), respectively.

Senescence-associated $\beta$-galactosidase assay. $\beta$-Galactosidase assay was used for assessing senescence of used cells using a Senescence-associated $\beta$-galactosidase Staining kit (cat. no. C0602; Beyotime Institute of Biotechnology, Haimen, China) as previously described $(22,23)$. Briefly, passage 3 and 10 ADSCs were washed in PBS, fixed for $10 \mathrm{~min}$ (room temperature) in $2 \%$ formaldehyde, washed, and incubated with the working solution containing $0.05 \mathrm{mg} / \mathrm{ml} 5$-bromo-4-chloro-3-in dolyl-b-d-galactopyranoside (X-gal). After incubation at $37^{\circ} \mathrm{C}$ for $12 \mathrm{~h}$ in the dark, the nucleus was counterstained with nuclear fast red (cat. no. N8002; Sigma-Aldrich; Merck KGaA, Darmstadt, Germany) and positive cells were observed under a light microscope at x200 magnification. The percentage of senescent cells was calculated by the number of blue, $\beta$-galactosidase-positive cells out of all cells in 6 different microscope fields. Senescence assays were performed in triplicate.

Preparation of co-culture conditioned media. To study the effects of cytokines from a co-culture system on MCF-7 cells,
ADSCs and MCF-7 co-culture conditioned media (AM-CM) was prepared. The same amount $\left(4 \times 10^{5}\right)$ of ADSCs and MCF-7 cells were plated in a flask and co-cultured to $80 \%$ confluency. Serum-free DMEM was added to the flask and cultured for $48 \mathrm{~h}$ at $37^{\circ} \mathrm{C}$ after being washed with PBS twice. The AM-CM was filtered and stored at $-80^{\circ} \mathrm{C}$ for a week, until further use.

Cell membrane labeling and co-culture in Matrigel. To track the interaction between cells, ADSCs and MCF-7 cells were stained with Vybrant ${ }^{\circledR}$ DiI Cell-Labeling Solution and DiO Cell-Labeling Solution, respectively (Invitrogen; Thermo Fisher Scientific, Inc.), according to the manufacturer's protocol. The same amount $\left(4 \times 10^{4}\right)$ of ADSCs and MCF-7 cells were mixed uniformly and seeded in Growth-factor-reduced Matrigel (cat. no. 356230; BD Biosciences, Franklin Lakes, NJ, USA) to fabricate a 3D culture system. The interactions between ADSCs and MCF-7 cells was observed continuously in Matrigel for $96 \mathrm{~h}$ at $37^{\circ} \mathrm{C}$ and $5 \% \mathrm{CO}_{2}$ using a confocal laser-scanning microscope (FV10i-W; Olympus Corporation, Tokyo, Japan). Co-culture assays were performed in quadruplicate.

Scanning electron microscopy (SEM). For scanning electron microscopy, the same amount $\left(4 \times 10^{4}\right)$ of ADSCs and MCF-7 cells were co-cultured at $37^{\circ} \mathrm{C}$ in Matrigel on round glass coverslips (Carl Roth GmbH \& Co. KG, Karlsruhe, Germany) in 12-well plates. After 2 days, co-culture samples were fixed in PBS $(1 \mathrm{ml})$ with $2 \%$ glutaraldehyde and incubated at $25^{\circ} \mathrm{C}$ for $60 \mathrm{~min}$. Samples were dehydrated in increasing concentrations of acetone, critical-point dried, fixed to stubs with colloidal silver, sputtered with gold using a MED 010 coater and examined under a S-3000N scanning electron microscope (Hitachi Ltd., Tokyo, Japan). An acceleration voltage of $20 \mathrm{kV}$ was used, and images were observed using S-3000N scanning electron microscope (Hitachi, Ltd.).

In vitro Transwell migration assay. Adipose stromal cells (ASC) migration assays were performed in triplicate using Transwell migration chambers $(8-\mu \mathrm{m}$ pore size; BD Biosciences). ADSCs $\left(3 \times 10^{3}\right)$ were plated in the upper wells, whereas MCF-7 cells $\left(3 \times 10^{3}\right)$ or AM-CM $(600 \mu l)$ were dispensed in the lower chamber. Controls were represented by serum-free DMEM. After $24 \mathrm{~h}$ of incubation at $37^{\circ} \mathrm{C}$, cells that remained on the top of the filter were scrubbed off, and cells that had migrated to the underside of the filter were fixed in methanol and stained with DAPI for $30 \mathrm{~min}$ at $25^{\circ} \mathrm{C}$. Migrated cells were manually counted under a fluorescence microscope. Migration assays were performed in triplicate.

To further investigate the mechanisms underlying the cells migration in this co-culture system, MCF-7 cells $\left(1 \times 10^{5}\right)$ were co-cultured with ADSCs cells $\left(1 \times 10^{5}\right)$ in Matrigel. MCF-7 alone served as the control. Cells in both groups were collected for gene analysis at day 1, 5, 9.

Tumorsphere formation in vitro. To investigate the tumorsphere formation capacity of MCF-7 cells under the influence of either contact or secretion signals of ADSCs, MCF-7 cells $\left(1 \times 10^{5}\right)$ were either co-cultured with ADSCs $\left(1 \times 10^{5}\right)$ or treated with $1 \mathrm{ml}$ AM-CM in Matrigel in 6-wells plates. MCF-7 cells $\left(1 \times 10^{5}\right)$ alone served as the control. The diameters of tumorspheres in four random fields of each well were counted and 
imaged. Tumorsphere formation assays were performed in triplicate.

To further investigate the effects of cytokines from a co-culture system on tumorsphere formation of MCF-7 cells, MCF-7 cells $\left(1 \times 10^{5}\right)$ were treated with $1 \mathrm{ml} \mathrm{AM-CM}$ (replaced every 3 days) in Matrigel in 6-wells plates. MCF-7 cells $\left(1 \times 10^{5}\right)$ alone served as the control. On day 1, 5 and 9, the Matrigel cultures were made into single-cell suspensions using Dispase (10 mg/ml; Roche Diagnostics, Basel, Switzerland) and cells in both groups were collected for subsequent gene analysis.

Reverse transcription-quantitative polymerase chain reaction (RT-qPCR). The co-cultures and MCF-7 cells alone that were cultured on Matrigel were made into single-cell suspensions using Dispase (10 mg/ml; Roche Diagnostics). Sample RNA was extracted using TRIzol ${ }^{\circledR}$ Reagent (Invitrogen; Thermo Fisher Scientific, Inc.) and used for cDNA synthesis with the DBI-2220 Bestar ${ }^{\circledR}$ qPCR RT Kit (DBI Bioscience, Ludwigshafen, Germany) according to the manufacturer's protocols. qPCR was conducted using a customized All-in-One ${ }^{\mathrm{TM}}$ qPCR Primer Array (GeneCopoeia, Inc., Rockville, MD, USA) and the ABI 7500 Fast Real-Time PCR system (Applied Biosystems; Thermo Fisher Scientific, Inc.). The primers used in the present study were: Macrophage inflammatory protein (MIP)-1 $\delta$, forward 5'-CCACTCAAC ATACTGCCTTCTA-3', and reverse 5'-AGTGTAGGAACC CTGCATTAC-3'; MIP-3 $\alpha$, forward 5'-CCAAAGAACTGG GTACTCAACA-3', and reverse 5'-GAGTAGCAGCACTGA CATCAA-3'; SOX2, forward 5'-GAGAGAGAAAGAAAG GGAGAGAAG-3', and reverse 5'-GAGAGAGGCAAACTG GAATCA-3'; OCT4, forward 5'-GGAGGAAGCTGACAA CAATGA-3', and reverse 5'-CTCTCACTCGGTTCTCGA TACT-3'; E-Cadherin, forward 5'-CTCGACACCCGATTC AAAGT-3', and reverse 5'-CCAGGCGTAGACCAAGAA AT-3'; Vimentin, forward 5'-GATTCACTCCCTCTGGTT GATAC-3', and reverse 5'-GTCATCGTGATGCTGAGA AGT-3'; and $\beta$-actin, forward 5'-GGACCTGACTGACTACCT CAT-3', and reverse 5'-CGTAGCACAGCTTCTCCTTAAT-3'. Thermocycling conditions were as follows: $95^{\circ} \mathrm{C}$ for $10 \mathrm{~min}$; followed by 40 cycles of $10 \mathrm{sec}$ at $95^{\circ} \mathrm{C}$ and $20 \mathrm{sec}$ at $55^{\circ} \mathrm{C}$. PCR specificity was assessed by the $2^{-\Delta \Delta \mathrm{Cq}}$ method (24); $\beta$-actin was used as an endogenous reference gene and for normalization.

Western blot analysis. The Matrigel cultures were made into single-cell suspensions using Dispase $(10 \mathrm{mg} / \mathrm{ml}$; Roche Diagnostics). Protein was extracted from cells $\left(1 \times 10^{6}\right)$ using M-PER Mammalian Protein Extraction Reagent (Thermo Fisher Scientific, Inc.) and quantification of protein lysates was conducted with the Bradford method. Protein products (60 $\mu \mathrm{g} / \mathrm{lane})$ were separated using 10\% SDS-PAGE and subsequently transferred overnight onto a polyvinylidene difluoride membranes (EMD Millipore, Billerica, MA, USA). Membranes were blocked in $5 \%$ milk for $1 \mathrm{~h}$ at $25^{\circ} \mathrm{C}$ and incubated with the following primary antibodies: Anti-E-Cadherin [1:500; Cell Signaling Technology (CST), Inc., Danvers, MA, USA; cat. no. 3195]; or anti-Vimentin antibody (1:500; CST, Inc.; cat. no. 5741). The membranes were cultured with horseradish peroxidase-conjugated anti-rabbit immunoglobulin $\mathrm{G}$ secondary antibody (1:10,000; cat. no. 111-035-003; Jackson ImmunoResearch Laboratories, Inc., West Grove, PA, USA) for $30 \mathrm{~min}$ at $25^{\circ} \mathrm{C}$, and proteins were visualized with the WesternBreeze Chemiluminescent Detection kit (Thermo Fisher Scientific, Inc.). $\beta$-actin (1:1,000; cat. no. 4970; CST, Inc.) served as an internal control.

Tumor-bearing mice preparation and in vivo imaging of ADSCs homing to tumors. Female nude mice ( $\mathrm{n}=9$; age, 4-5 weeks; weight, 13-15 g) were purchased from the Southern Medical University Laboratory Animal Center and were maintained in microisolator cages at the Animal Experiment Center of Nanfang Hospital. Mice were housed in a pathogen-free animal facility $\left(25 \pm 2^{\circ} \mathrm{C} ; 55 \%\right.$ humidity) with ad libitum access to standard food and water, and a 12-h light/dark cycle. Tumor-bearing models were prepared as previously described (25). Briefly, MCF-7 cells $\left(2 \times 10^{6}\right)$, resuspended in $0.5 \mathrm{ml}$ PBS, were subcutaneously injected into each side of groin adipose pad of the nude mouse. Tumor formation was observed at the groin area 2-3 weeks following the MCF-7 cells injection and the tumor-bearing mice were used in subsequent in vivo experiments. A cell tracer Vybrant ${ }^{\circledR}$ DiI was used to trace ADSCs in vivo; DiI labeling solution was prepared following the manufacturer's protocol. Briefly, $5 \times 10^{5}$ ADSCs in $1 \mathrm{ml}$ of PBS were mixed with $5 \mu 1$ of DiI labeling solution and incubated for $15 \mathrm{~min}$ at $37^{\circ} \mathrm{C}$. After labeling, cells were washed and injected into the tail veins of tumor-bearing mice. Bioluminescence imaging of mice and excised organs (lung, heart, liver and kidney) and tumors was conducted to trace the ADSCs using an in vivo Multispectral Imaging Systems FX, bioluminescence imaging system (Carestream Health, Inc., Rochester, NY, USA) at 4 weeks following ADSC injection.

Xenograft assays in nude mice and frozen sectioning. Female nude mice (age, 4-5 weeks; weight, 13-15 g; n=30) were purchased from the Southern Medical University Laboratory Animal Center and were maintained as aforementioned. For xenograft experiments, MCF-7 cells $\left(1 \times 10^{6}\right)$ mixed with ADSCs $\left(1 \times 10^{6}\right)$ were injected into the right groin adipose pad, whereas MCF-7 cells $\left(1 \times 10^{6}\right)$ alone injected into the left groin adipose pad served as a control. Tumor volumes were measured using Vernier calipers every 4 days for 32 consecutive days and calculated using the following formula: Tumor volume $=\left(\right.$ length $\mathrm{x}$ width $\left.^{2}\right) / 2$, following previously published protocols $(26,27)$. The mice were sacrificed at 32 days post-inoculation by cervical dislocation after being anesthetized by $1 \%$ pentobarbital $(40 \mathrm{mg} / \mathrm{kg})$, and the tumor samples were removed for further analysis.

For frozen sections, fresh excised tumor samples were embedded in frozen section embedding medium optimal cutting temperature (OCT) compound and were frozen rapidly at $-20^{\circ} \mathrm{C}$. The frozen samples were then subjected to hematoxylin and eosin $(\mathrm{H} \& \mathrm{E})$ staining, following a previously published protocol (28). Briefly, the frozen samples were cryosectioned into $5-\mu \mathrm{m}$ slices and mounted onto charged microscope slides. The slices were washed with distilled water and $30 \%$ isopropanol to remove the OCT compound, and stained with the H\&E working solution (hematoxylin for $4 \mathrm{~min}$ and eosin for $30 \mathrm{sec}$ ) at $25^{\circ} \mathrm{C}$. Following staining, the sections were mounted with neutral balata (Nanjing KeyGen Biotech Co., Ltd., Nanjing, China) for $30 \mathrm{~min}$ at $25^{\circ} \mathrm{C}$ and observed under a light microscope. 

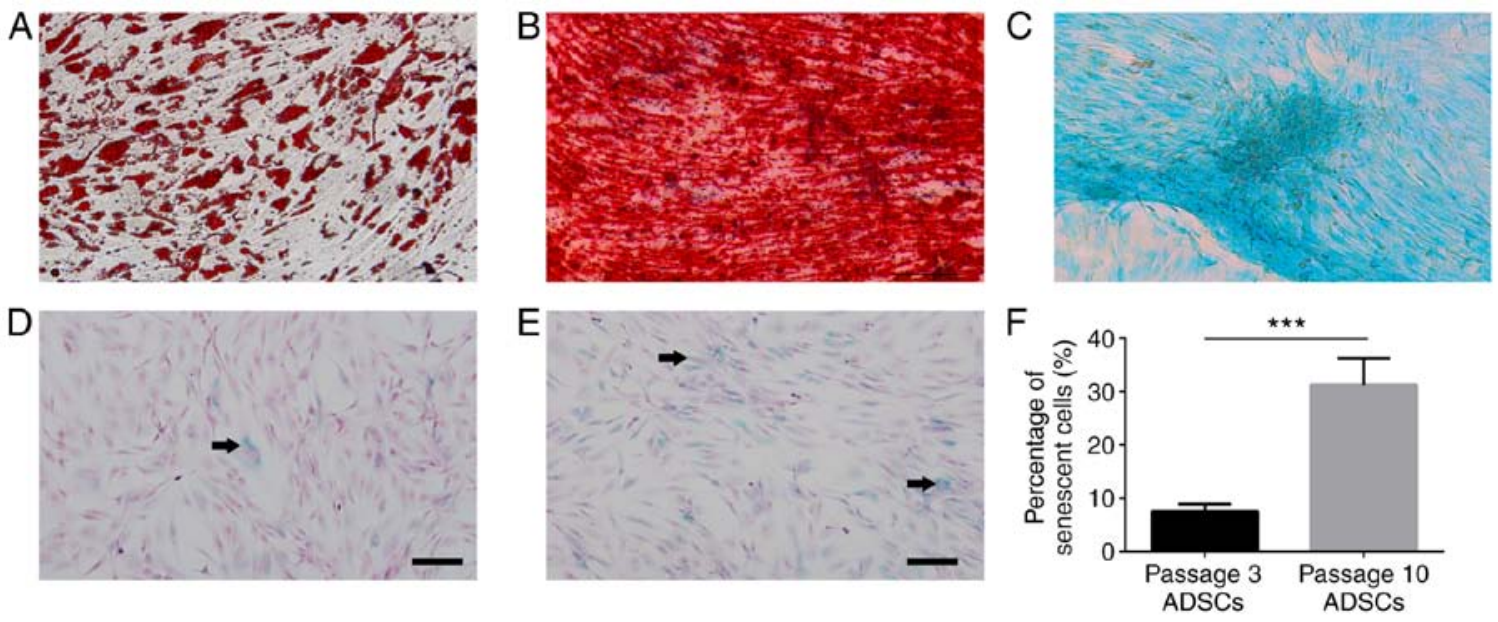

Figure 1. Multi-lineage differentiation potential and senescence evaluation of ADSCs. (A) Oil Red O; (B) Alizarin red and (C) Alcian blue staining (D and E) Representative microscopic fields of acid $\beta$-galactosidase (blue) staining in cells and (F) quantification of $\beta$-galactosidase-positive cells. Black arrows indicate senescent cells. Experiments were repeated 3 times. ${ }^{* * *} \mathrm{P}<0.001$. Scale bar, $100 \mu \mathrm{m}$. ADSCs, adipose-derived mesenchymal stem cells.
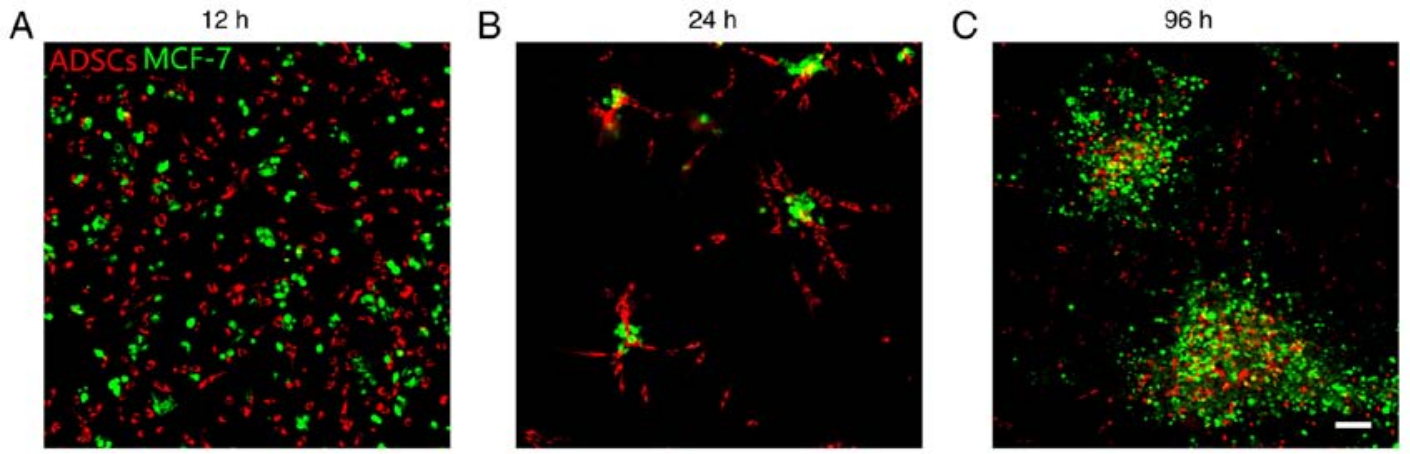

Figure 2. Interaction between ADSCs and MCF-7 cells in vitro. (A) ADSCs and MCF-7 cells display a uniform distribution at 12 h after cell implantation. (B) At 24 h, ADSCs were touching and surrounding MCF-7 cells. (B) At 96 h, ADSCs were observed inside MCF-7 tumorspheres. Experiments were repeated 4 times. Scale bar, $100 \mu \mathrm{m}$. ADSCs, adipose-derived mesenchymal stem cells.

Statistical analysis. Quantitative results were expressed as the means \pm standard deviation. The comparison between co-culture or AM-CM treated samples at different time points with MCF-7 cells was examined using the Student's t-test with SPSS 22.0 software (IBM Corp., Armonk, NY, USA). Multiple comparisons of migrated ADSCs in Transwell migration assay and tumorspheres diameter in the tumorsphere formation assays were performed using one-way analysis of variance and the least significant difference post hoc analysis was performed to ascertain significance between groups. $\mathrm{P}<0.05$ was considered to indicate a statistically significant difference.

\section{Results}

ADSCs characterization and senescence evaluation. The isolated ADSC cells expressed lipid droplets, matrix mineralization, cartilage-specific proteoglycans and were positive for Oil Red O (Fig. 1A), Alizarin red (Fig. 1B), and Alcian blue (Fig. 1C). Senescence degree of ADSCs was evaluated by in situ senescence-associated- $\beta$-galactosidase assay. Few senescent cells were observed in passage 3 ADSCs (Fig. 1D), whereas numerous senescent cells were observed in passage 10 ADSCs (Fig. 1E). Quantification analysis revealed that there was a significantly decreased percentage of blue, $\beta$-galactosidase-positive cells in passage 3 compared with that in the passage $10 \mathrm{ADSCs}$ (Fig. 1F).

Tumor tropism of ADSCs, chemokine expression and cell interactions. ADSCs and MCF-7 cells were evenly distributed at $12 \mathrm{~h}$ after co-culture (Fig. 2A). At $24 \mathrm{~h}$, ADSCs were touching and surrounding MCF-7 cells (Fig. 2B). ADSCs were observed inside MCF-7 tumorspheres at $96 \mathrm{~h}$ after co-culture (Fig. 2C). Based on this observation, it was hypothesized that MCF-7 cells may exert a tropism effect on ADSCs. The migration of ADSCs towards MCF-7 cells was investigated in vivo and in vitro. In the Transwell system, quantification of migrated cells revealed that the migration activity of ADSCs from the upper wells was significantly promoted by MCF-7 cells in the lower chambers and, to a lesser extent, by the putative secreted cytokines from the co-culture system compared with the control (Fig. 3A and B). The expression levels of the inflammatory chemokines MIP-1 $\delta$ and MIP-3 $\alpha$ in the co-culture system (ADSCs + MCF-7) were significantly increased compared with the control (MCF-7/DMEM; Fig. 3C and D). To trace fluorescence-labeled ADSCs, mice were first observed under a 
A

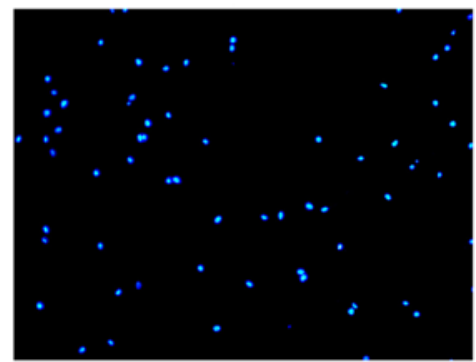

B

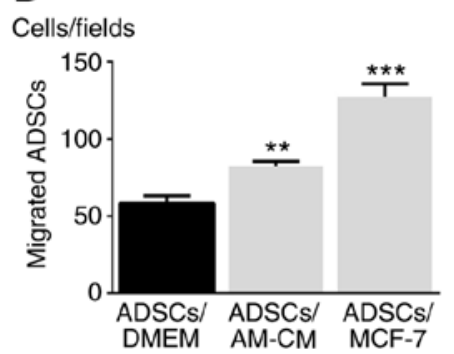

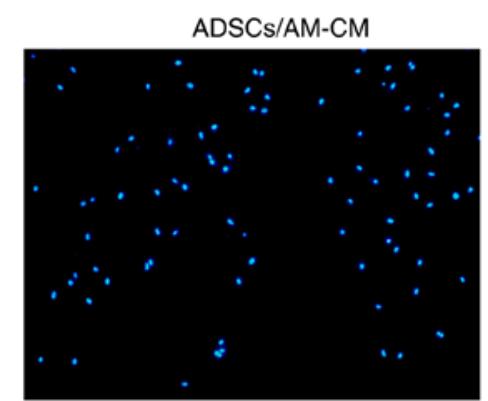

C

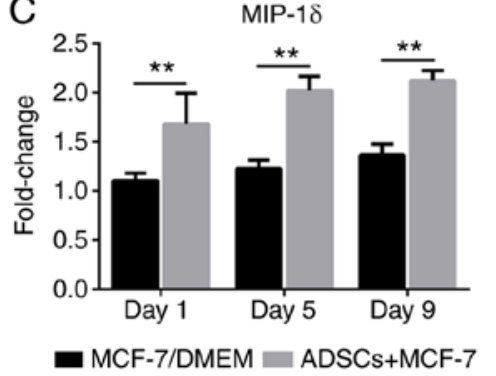

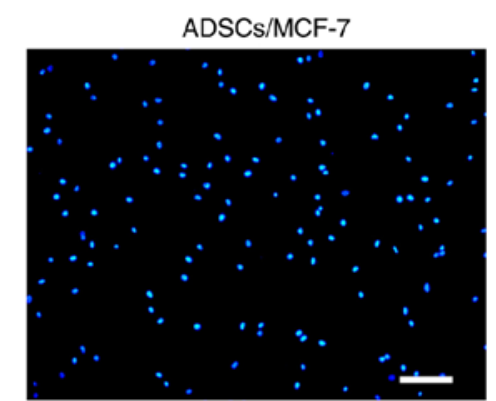

D

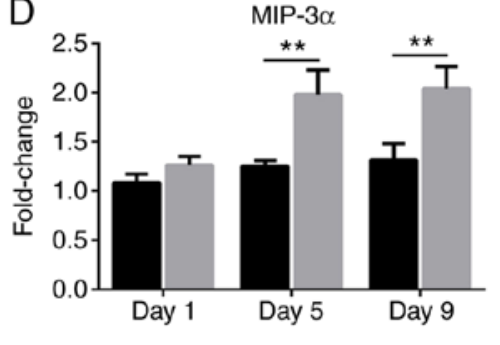

- MCF-7/DMEM ADSCs+MCF-7

Figure 3. MCF-7 cells induce ASC migration and chemokines expression in vitro. (A) ADSCs in upper chamber were co-cultured MCF-7 cells or AM-CM in lower chamber, while DMEM in lower chamber severed as a control and (B) quantification of the ADSCs migrated at the bottom of the insert membrane;

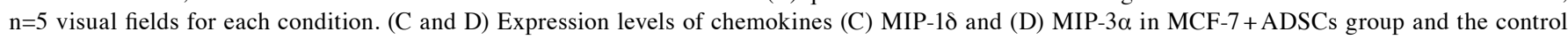
MCF-7/DMEM group, as measured by reverse transcription-quantitative polymerase chain reaction. Experiments were repeated 3 times. The results are presented as mean \pm standard deviation; ${ }^{* *} \mathrm{P}<0.01,{ }^{* * *} \mathrm{P}<0.001$. Scale bar, $100 \mu \mathrm{m}$. ADSCs, adipose-derived mesenchymal stem cells; AM-CM, ADSCs and MCF-7 co-culture conditioned media; ASC, adipose stromal cells; MIP, macrophage inflammatory protein.
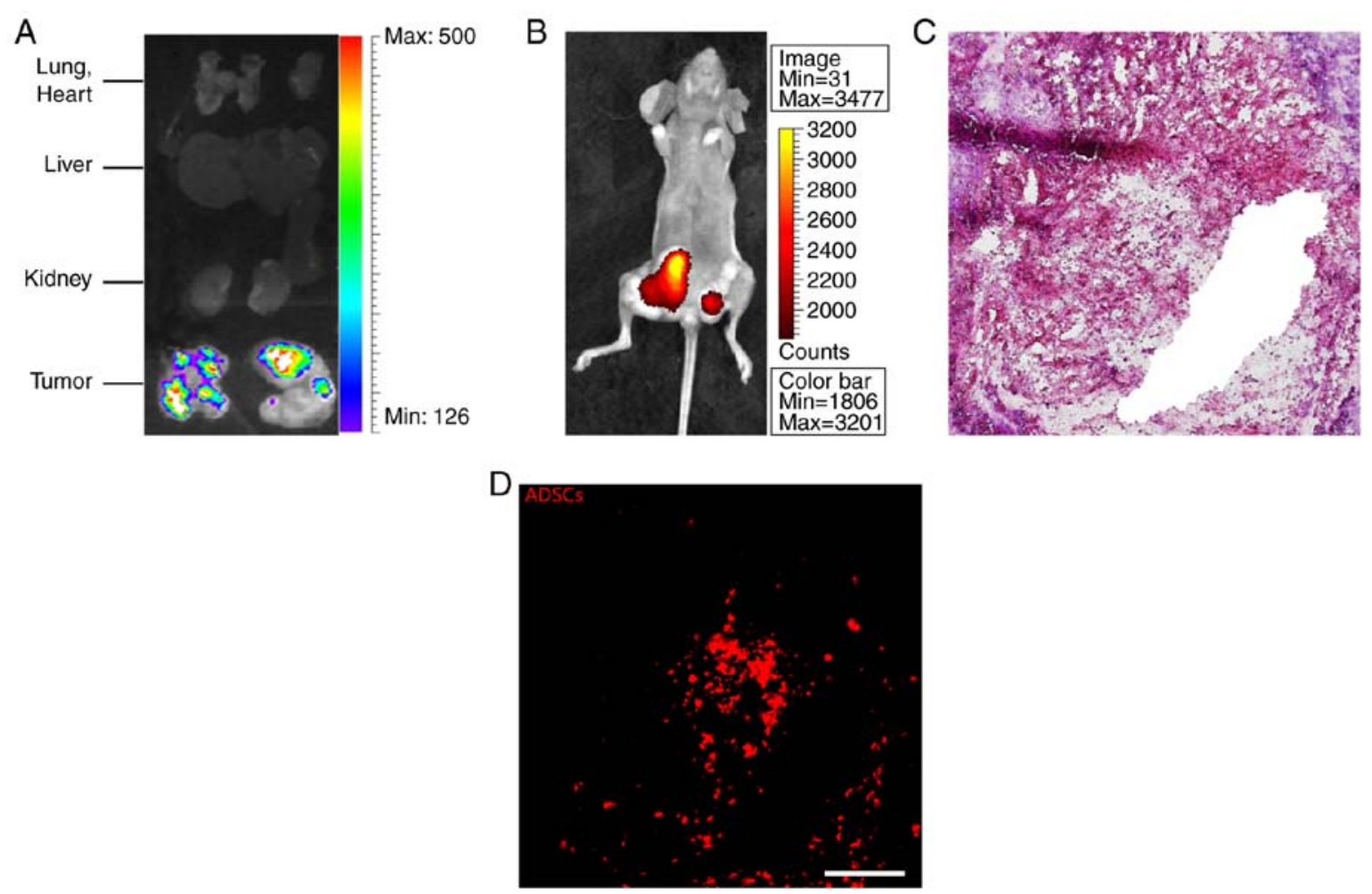

Figure 4. Tumor tropism of ADSCs in vivo. (A and B) Tracing of ADSCs after tail veins injection using a bioluminescence imaging system. (C) Hematoxylin and eosin staining and (D) the corresponding fluorescence image of tumor sample. Experiments were repeated 3 times. Scale bar, $200 \mu \mathrm{m}$. ADSCs, adipose-derived mesenchymal stem cells.

bioluminescence imaging live fluorescence system and subsequently the tumors and important organs (lung, heart, liver and kidney) were carefully dissected from mice and observed under the same system. The results revealed that the fluorescence signal was mainly concentrated in tumor tissue and nearly no signal was observed in other important organs (Fig. 4A and B). H\&E staining and DiI-labelled ADSCs were observed in sections (Fig. 4C and D, respectively). Collectively, these 

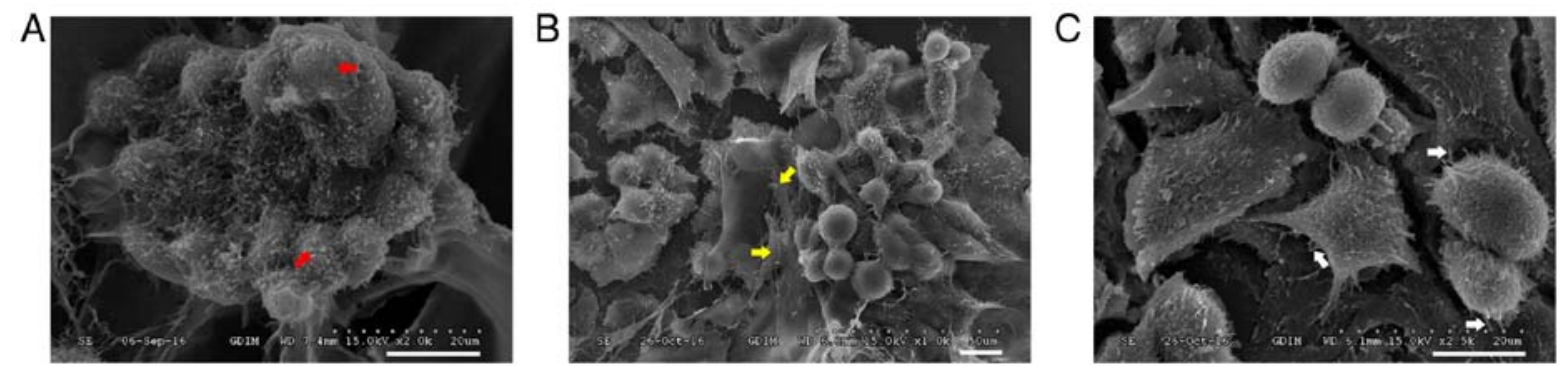

Figure 5. Scanning electron microscopy analysis of ADSCs and MCF-7 interaction. (A) Tumorspheres formation of spherical MCF-7 cells (red arrows) in Matrigel. (B) Tumorspheres were surrounded by flatly spread cells with typical ADSCs morphology (yellow arrows). (C) Intercellular connections (white arrows) between ADSCs and MCF-7 cells. Scale bar, $10 \mu \mathrm{m}$. ADSCs, adipose-derived mesenchymal stem cells.

A

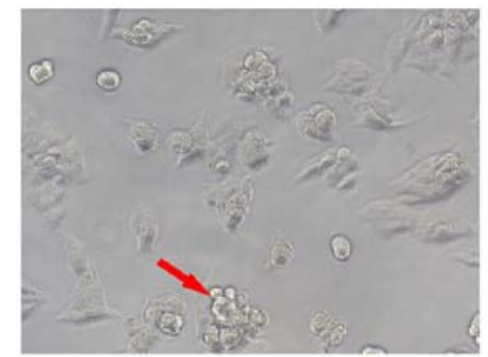

B

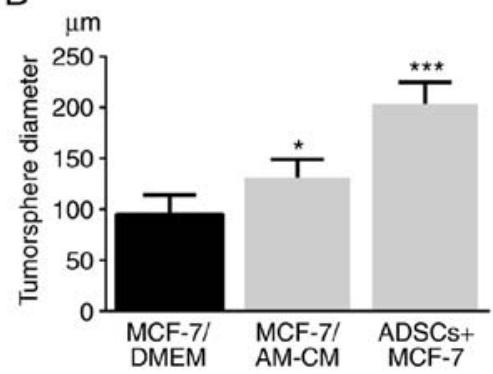

MCF-7/AM-CM
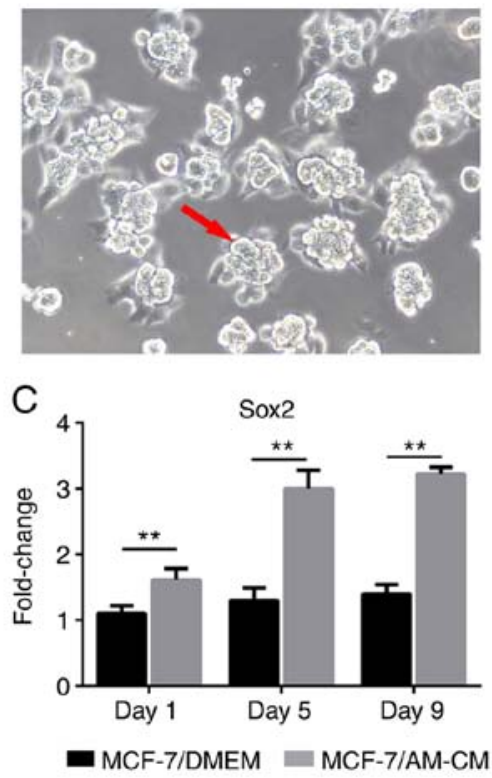

ADSCS+MCF-7
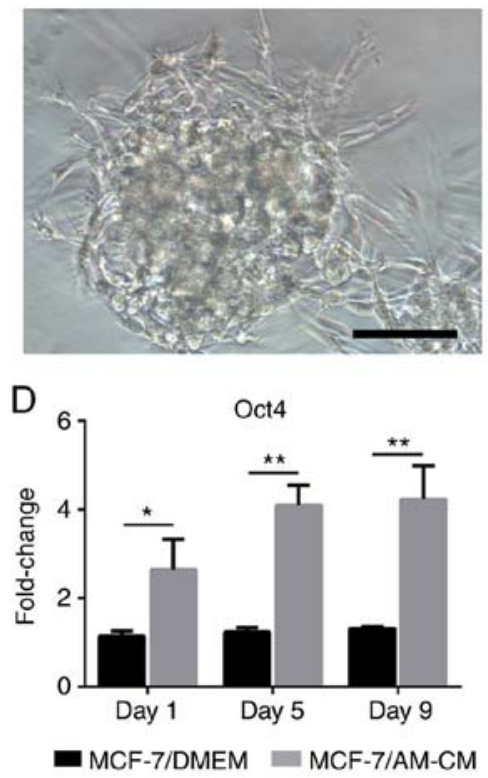

Figure 6. ADSCs enhance tumorspheres formation of MCF-7 cells. (A) Analysis of ADSC-induced tumorsphere formation effects on MCF-7 cells. (B) Quantification of tumor diameter in different groups. (C and D) Expression levels of CSC markers in AM-CM-treated MCF-7 cells and the control MCF-7 cells, as measured by reverse transcription-quantitative polymerase chain reaction. The results are presented as mean \pm standard deviation; ${ }^{*} \mathrm{P}<0.05,{ }^{* *} \mathrm{P}<0.01$ and ${ }^{* * *} \mathrm{P}<0.001$. Scale bar, $100 \mu \mathrm{m}$. ADSCs, adipose-derived mesenchymal stem cells; AM-CM, ADSCs and MCF-7 co-culture conditioned media; ASC, adipose stromal cells; CSC, cancer stem cell; OCT, Octamer-binding protein; SOX, Sex determining region Y-box.

results suggested that ADSCs mainly migrated to tumor site following intravenous injection, possibly through the circulatory system.

The morphological appearance of co-cultures of ADSCs and MCF-7 cells was observed by a scanning electron microscope. Spherical MCF-7 cells grew into tumorspheres with irregular surfaces in Matrigel substrate (Fig. 5A). Tumorspheres were surrounded by ADSCs, which were recognized by their flatly spread morphology (Fig. 5B). At higher magnification, the construction of connections between ADSCs and MCF-7 cells were observed (Fig. 5C).

ADSCs enhance tumorsphere formation, cancer stem cell (CSC) marker expression, and in vivo tumor formation. Tumorsphere formation, which is a property of cancer stem cells, was observed in our 3D culture system. MCF-7 cells co-cultured with ADSCs exhibited a significant capacity to form tumorspheres, whereas the AM-CM also exhibited a marked effect on tumorsphere formation (Fig. 6A).
Quantitative analysis revealed that tumorspheres in co-culture groups (ADSCs + MCF-7) were larger than those treated with AM-CM (MCF-7/AM-CM). As a control, MCF-7 cells alone (MCF-7/DMEM) in Matrigel exhibited the weakest tumorsphere formation capacity (Fig. 6B). RT-qPCR analysis further revealed a higher expression of key CSC markers SOX2 and OCT4 in AM-CM treated MCF-7 (MCF-7/AM-CM) than in the MCF-7 cells alone (MCF-7/DMEM; Fig. 6C and D).

To further evaluate the effect of ADSCs on tumor growth of MCF-7 cells in vivo, a xenograft model we established, in which MCF-7 cells were mixed with or without ADSCs and were then inoculated subcutaneously into nude mice. As shown in Fig. 7A and B, the tumor volume of the ASC-treated group was markedly increased compared with that of the control group. $\mathrm{H} \& \mathrm{E}$ staining revealed that the necrotic area in ASC-treated tumor tissue was considerably reduced compared with that in controls (Fig. 7C and D). These results indicate that ADSCs may enhance the stemness expression and tumor-promoting properties of MCF-7 cells. 
A
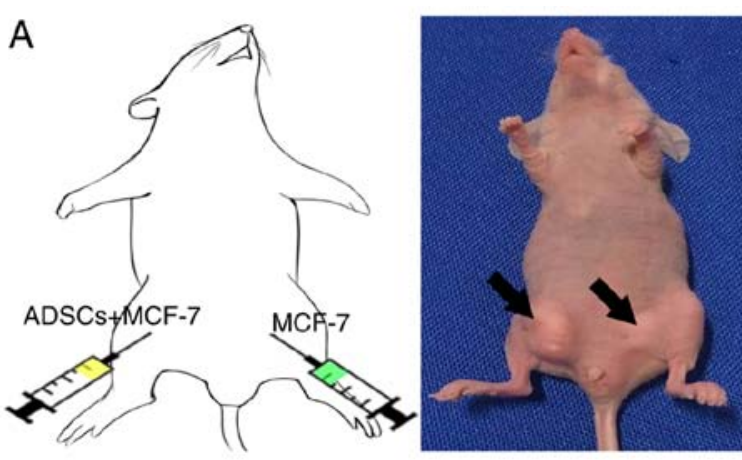

C
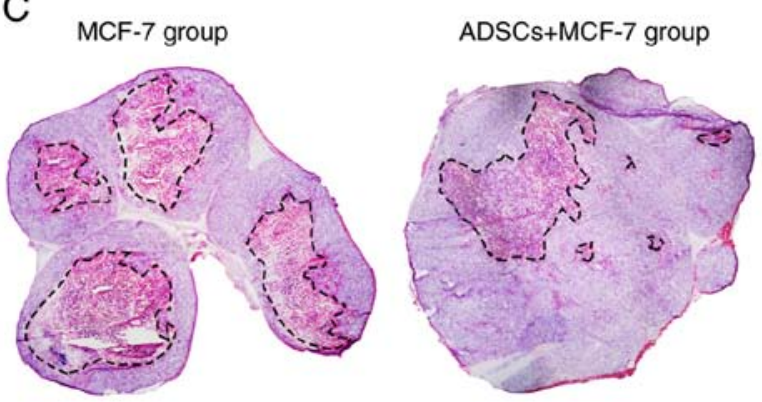
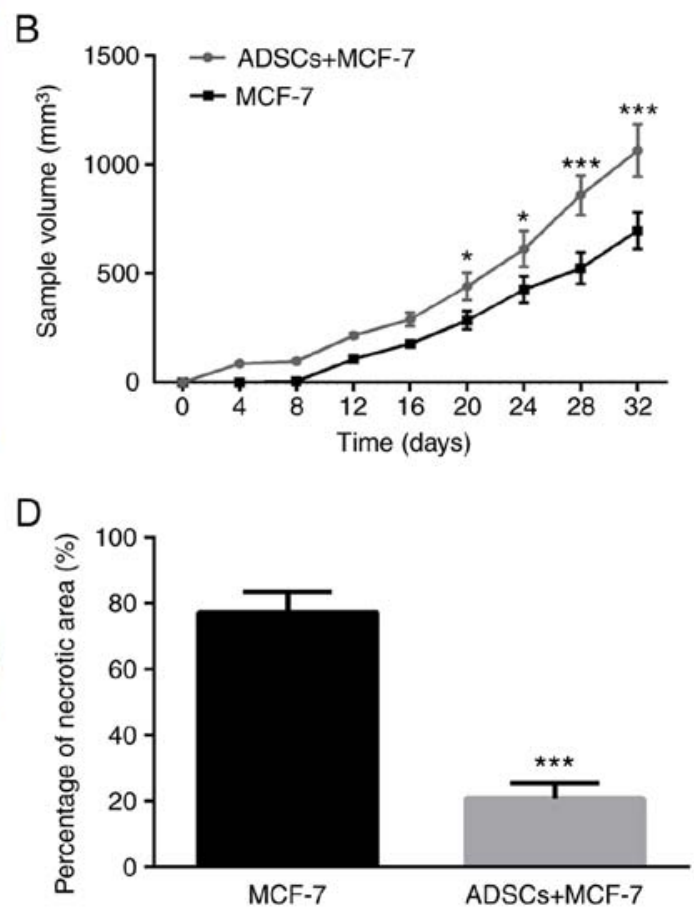

Figure 7. Effects of ADSCs on tumorigenesis of MCF-7 cells in vivo. (A) Nude mice were injected with ADSCs alone or mixed with MCF-7. The tumors were indicated by black arrows. (B) Quantification of tumor volume. (C) Hematoxylin and eosin staining of tumor tissue and (D) quantification of the necrotic area in tumor tissue. The results are presented as mean \pm standard deviation; ${ }^{*} \mathrm{P}<0.05,{ }^{* * *} \mathrm{P}<0.001$. Scale bar, $100 \mu \mathrm{m}$. ADSCs, adipose-derived mesenchymal stem cells.

Expression of epithelial and mesenchymal markers. In view of the morphological changes of MCF-7 cells in tumorspheres, whether the acquisition of stemness properties is associated with the epithelial to mesenchymal transition (EMT) was investigated. Representative EMT markers were analyzed in the AM-CM treated MCF-7 cells group (MCF-7/AM-CM) and the control MCF-7 cells group (MCF-7/DMEM). Results revealed reduced E-Cadherin (epithelial marker) and increased Vimentin (mesenchymal marker) mRNA expression in the AM-CM treated MCF-7 cells compared with the control MCF-7 cells (Fig. 8A). Protein expression analysis revealed a similarly decreased E-Cadherin and increased Vimentin level in AM-CM treated MCF-7 cells compared with control MCF-7 cells (Fig. 8B), indicating that the ADSCs may induce the EMT in MCF-7 cells.

\section{Discussion}

Although stem cells are a promising source for cell therapy in regenerative medicine, the potential pro- or anti-tumoral actions of these cells remain controversial (29). Adipose tissue is an abundant, accessible and rich source of ADSCs, and adipose transplantation is gaining increasing interest among the plastic surgery techniques currently available to reconstruct the breast after mastectomy for breast cancer. However, recent scientific attention has turned to whether grafted ADSCs within adipose tissue may increase the risk of cancer recurrence $(14,19,30-33)$.

In the present study, ADSCs and MCF-7 cells were co-cultured in a 3D model to investigate the impacts of ADSCs on breast cancer cells. It was found that the co-culture system resulted in migration of ADSCs to MCF-7 cells and simultaneously promoted tumor progression. Similar to other immune cells, MSCs exhibit tropism for sites of tissue damage and the tumor microenvironment (34-36). Various studies indicated that MSCs migrated to sites of inflammation and diseased tissues when injected systemically $(37,38)$. In contrast, other studies have reported that MSC migration can be induced by conditioned medium from colorectal cancer (39), gliomas $(40,41)$, and breast cancer (42) cells in vitro. To date, the majority of the studies on MSC tumor tropism were performed with bone marrow-derived MSCs, and limited data are available regarding the ADSCs from adipose tissue. In the present study, it was observed that MCF-7 cells induced efficient ASC tropism. MSC migration to tumors is thought to be due to chemokines secreted by tumor cells, but this needs to be validated. Chemokines were originally identified as potent attractants for leukocytes, such as neutrophils and monocytes, and were generally regarded as mediators of acute and chronic inflammation (inflammatory chemokines) (43). Additionally, chemokines and their receptors have been identified as actors promoting MSC tumor tropism and initiation or cancer progression (43-48). Among these inflammatory chemokines, MIP-1 $\delta$ and MIP-3 $\alpha$ are considered as key considered factors in inducing MSC migration (39). MIP-1 $\delta$ and MIP-3 $\alpha$ are cytokines that mainly regulate immune cell migration (49) and were recently considered serum biomarkers for hepatocellular carcinoma (50). Lejmi et al (36) investigated the migration of human bone marrow-derived MSCs induced by conditioned medium of Huh-7 hepatoma cells, detecting increased levels of MIP-1 $\delta$ and MIP-3 $\alpha$ in Huh-7-CM using a human cytokine antibody array. Transwell migration assay showed that recombinant MIP-1 $\delta$ and MIP-3 $\alpha$ increased bone marrow-derived MSC migration and that inhibition of antibodies against 

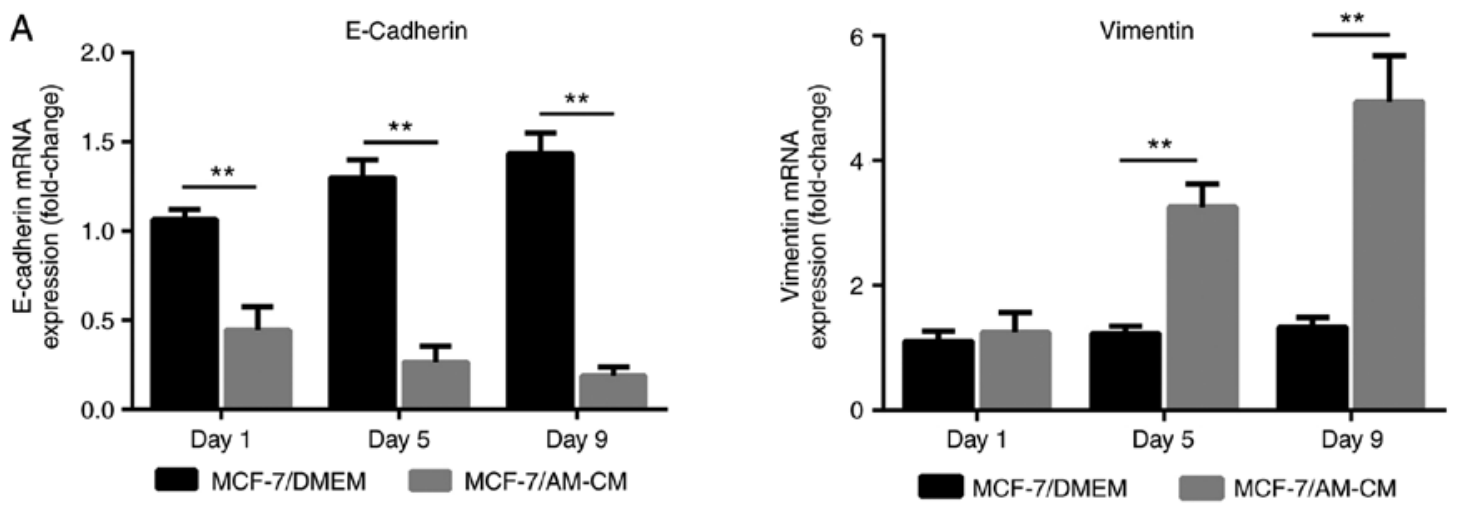

B
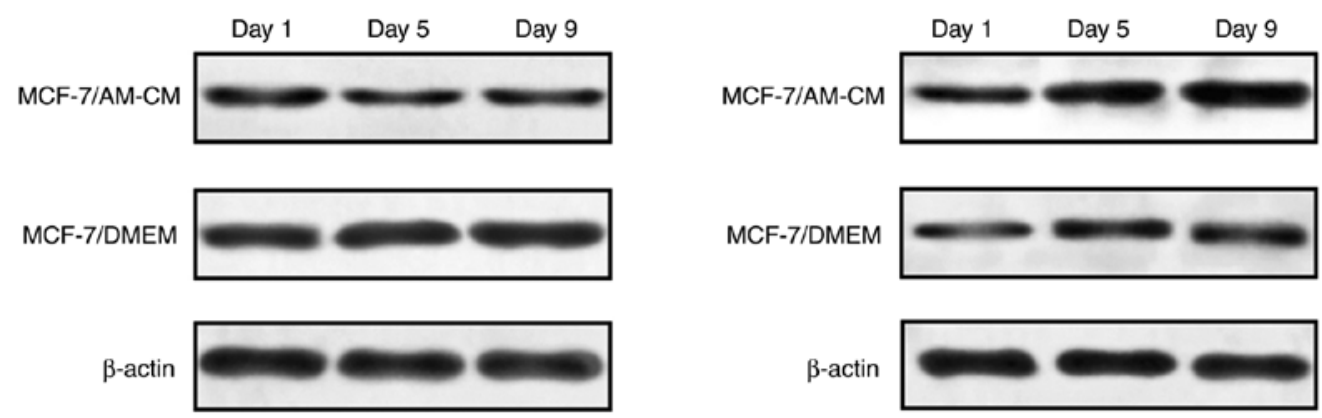

Figure 8. ADSCs induce EMT in MCF-7 cells. (A and B) E-Cadherin and Vimentin (A) mRNA and (B) protein expression levels were measured by reverse transcription-quantitative polymerase chain reaction and western blot analysis, respectively, in MCF-7 cells alone or AM-CM treated MCF-7 cells at different time points. Scale bar, $100 \mu \mathrm{m} ;{ }^{* *} \mathrm{P}<0.01$. ADSCs, adipose-derived mesenchymal stem cells; AM-CM, ADSCs and MCF-7 co-culture conditioned media; EMT, epithelial mesenchymal transition.

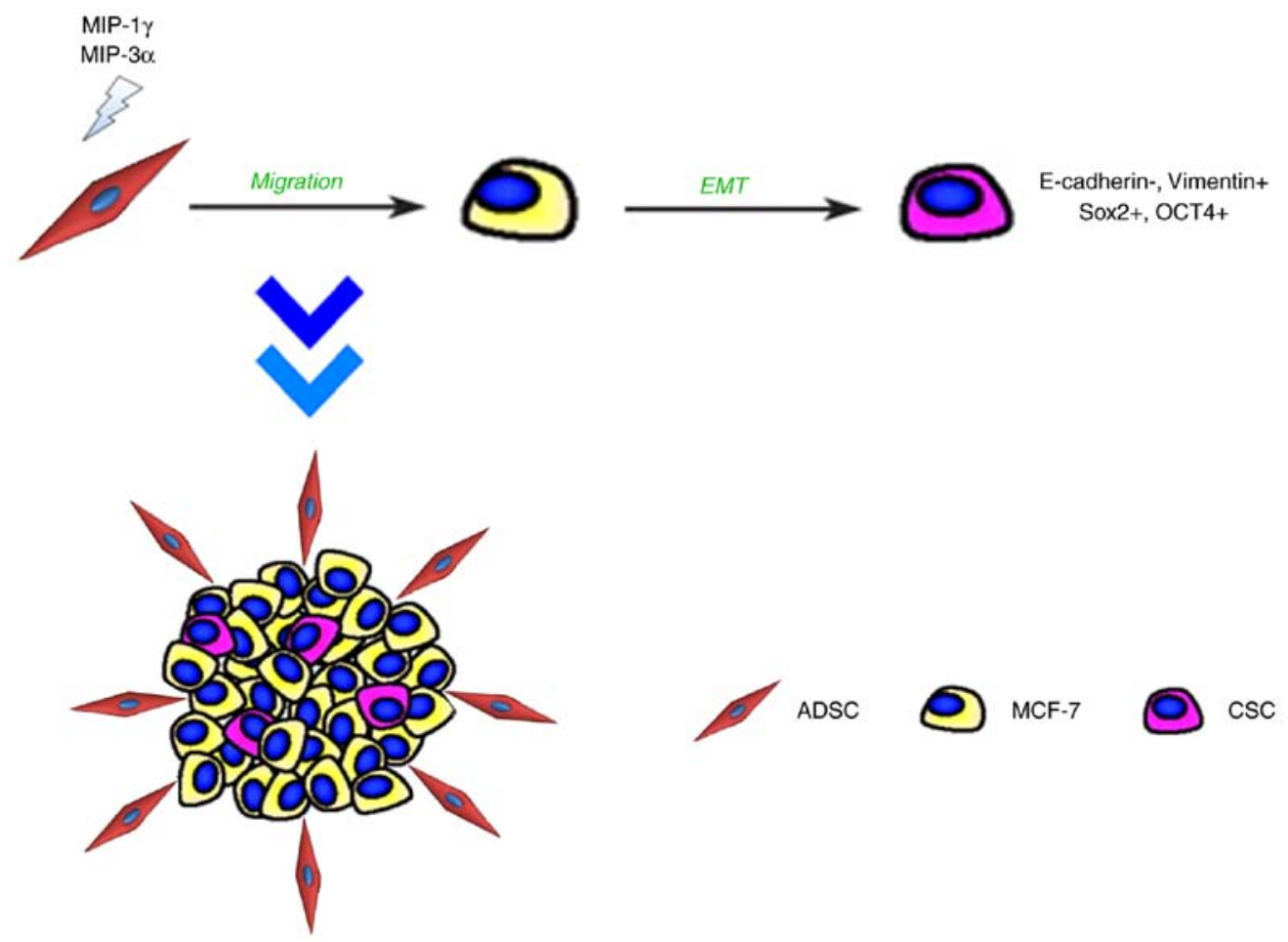

Figure 9. Schematic diagram presenting the potential mechanisms for the interaction between ADSCs and MCF-7 cells. ADSCs, adipose-derived mesenchymal stem cells; AM-CM, ADSCs and MCF-7 co-culture conditioned media; CSC, cancer stem cells; EMT, epithelial mesenchymal transition; MIP, macrophage inflammatory protein; OCT, Octamer-binding protein; SOX, Sex determining region Y-box.

MIP-18 and MIP-3 $\alpha$ slightly decreased MSCs migration. Consistent with these results, increased expression levels of MIP-1 $\delta$ and MIP-3 $\alpha$ were detected in the co-culture system compared with the control, indicating that these two inflammatory chemokines may participate in ADSCs migration in the present study. 
Along with the migration of ADSCs to MCF-7 cells, aggregation and sphere-like structure formation of MCF-7 cells are also important features of the 3D co-culture system. Previous studies have reported that sphere-like structure formation of cancer cells in vitro indicates the acquisition of CSC properties in cancer cell subpopulations (51-53). CSCs are identified by high self-renewal capability, the capacity to grow as tumorspheres in vitro and tumor growth promotion in vivo $(54,57)$. In xenograft breast cancer models, MCF-7 and ADSCs co-injection induced notably faster tumor growth and fewer necrotic areas in tumor tissues than MCF-7 injection alone, suggesting the cancer-promoting activity of ADSCs in vivo. Prompted by these results, it could be assumed that tumorsphere and tumor tissue formation is associated with CSC generation. The CSC markers SOX2 and OCT4 has been reported to inhibit apoptosis and promote biological activity in CSCs $(55,56)$. SOX2 and OCT4 expression levels were increased in MCF-7 cells after treatment with AM-CM on Matrigel substrates. This result indicated that the tumorsphere formation in the co-culture system is likely associated with the stem-like transfer of MCF-7 cells influenced by the secretory cytokines from ADSCs.

Candidate CSCs have been identified in a variety of human malignancies, including leukemias, and a number of solid tumors, such as glioblastomas, medulloblastomas and carcinomas (57-60). The contributions of the EMT program in promoting cancer cells with stem-like properties have been well documented in many types of carcinoma. Mani et al (61) demonstrated a direct link between the EMT and epithelial stem cell properties. Using different EMT inducers, they showed that the induction of the EMT in human breast cancer cells accounted for the acquisition of their stem-like characteristics. The EMT is a key program during embryonic development, tissue remodeling, and cancer progress (62) and is characterized by the loss of epithelial characteristics coupled with the gain of mesenchymal properties. Furthermore, EMT process is associated with a mesenchymal-like breast cancer phenotype, including acquisition of invasive properties and the loss of cell-cell adhesion. These features are associated with a more aggressive phenotype and a poor prognosis (63). In direct co-culture systems, malignant tumorsphere formation was observed, indicating loss of contact inhibition. Hence, we hypothesized that co-culturing with ADSCs promoted the EMT of MCF-7 cells. As expected, gene expression analysis revealed a significant upregulation of the mesenchymal marker Vimentin and the downregulation of the epithelial marker E-Cadherin in AM-CM treated MCF-7 cells compared with the control, indicating the potential acquisition of EMT process in MCF-7 cells. Altogether, the present results indicated that the stem-like transfer of MCF-7 cells may be a consequence of the EMT induced by secretory cytokines from ADSCs.

Matrigel-based 3D co-culture system may be a convenient and rapid platform for studying cell interaction in tumor development $(64,65)$. Using this platform, it was demonstrated that the interaction between ADSCs and MCF-7 cells stimulated the expression of the chemokines MIP- $1 \delta$ and MIP- $3 \alpha$, which may act as a regulator inducing the migration activity of ADSCs toward breast cancer cells and to establish direct cell-cell contacts. Furthermore, it was demonstrated that ADSCs serve pro-malignant roles in MCF-7 cells through promoting the tumorsphere formation of MCF-7 cells, which are likely associated with CSC properties through the EMT process (Fig. 9). The promoted tumorigenicity was further confirmed in the in vivo xenotransplantation model. These results are important for safety concerns regarding the clinical application of ASC-based strategies, such as fat grafting, in post-oncologic breast reconstruction, interestingly because microscopic tumor cells may remain after tumor resection.

However, the present study is small and data is limited, several drawbacks should be resolved to fully clarify the precise mechanisms of ADSCs facilitating breast cancer development. First, although the procedure for ADSCs isolation and expansion is considered the most widely used method (66), these cultured cells are still heterogeneous, containing stem cells with different multipotential properties, committed progenitors, and differentiated cells, which in turn may affect the biological properties of the total population. Therefore, using a purified stem cell population from adipose tissue would help improve the study design and strengthen our conclusion. Second, MIP chemokines were not directly shown to act on the migration activity of ADSCs towards MCF-7 cell due to current limited conditions. According to previous studies, MIP cytokines mainly regulate immune cell migration (53) and were recently found to be important chemoattractants that induce MSC migration and further favor its differentiation (36). Using recombinant chemokines MIP-1 $\delta$ and MIP-3 $\alpha$, Lejmi et al (36) revealed that MSC migration was induced whereas addition of anti-MIP-1 $1 \delta$ and anti-MIP-3 $\alpha$ antibodies decreased the MSC migration activity. These results may help to demonstrate that MIP-1 $1 \delta$ and MIP-3 $\alpha$ may be involved in the migration of ADSCs to MCF-7 cells in the present study but using recombinant chemokines MIP-1 $\delta$ and MIP-3 $\alpha$ or knockdown of these genes to solidify this conclusion is still necessary in further studies. Third, interaction between the other types of breast cancer cells and ADSCs should be investigated in further studies to fully clarify the potential impacts of fat grafting on breast cancer cells in the clinic.

\section{Acknowledgements}

Not applicable.

\section{Funding}

The present study was supported by The National Natural Science Foundation of China (grant nos. 81471881, 81372083), Key Clinical Specialty Discipline Construction Program, Health Collaborative Innovation major projects of Guangzhou (grant no. 7414275040815), Natural Science Foundation of Guangdong Province of China (grant no. 2014A030310155), Entry Point Project of Guangdong Province of China (grant no. PY2014N036), Innovative project of Guangdong Province of China (grant no. 2014KQNCX046) and Administrator Foundation of Nanfang Hospital (grant no. 2014B009).

\section{Availability of data and materials}

The data sets used and/or analyzed during the present study are available from the corresponding author on reasonable request. 


\section{Authors' contributions}

YH conceived, designed the study and wrote the manuscript. YC and XW performed the experiments and analyzed the results. JG and FL designed and coordinated the study. All authors read and approved the manuscript and agree to be accountable for all aspects of the research in ensuring that the accuracy or integrity of any part of the work are appropriately investigated and resolved.

\section{Ethics approval and consent to participate}

All procedures performed in the present study involving human participants were approved by the Southern Medical University Institutional Review Board (Guangzhou, China) and the patient provided written informed consent to donate remaining tissues after liposuction. All procedures performed involving animal experiments were approved by the Nanfang Hospital animal ethic committee (permit no. NFYY201679) and was conducted in accordance with the ethical standards of the National Health and Medical Research Council China.

\section{Patient consent for publication}

Not applicable.

\section{Competing interests}

The authors declare that they have no competing interests.

\section{References}

1. Nelson HD, Zakher B, Cantor A, Fu R, Griffin J, O'Meara ES, Buist DS, Kerlikowske K, van Ravesteyn NT, Trentham-Dietz A, et al: Risk factors for breast cancer for women aged 40 to 49 years: A systematic review and meta-analysis. Ann Intern Med 156: 635-648, 2012.

2. Porter PL: Global trends in breast cancer incidence and mortality. Salud Publica Mex 51 (Suppl 2): S141-S146, 2009.

3. McGuire KP, Eisen S, Rodriguez A, Meade T, Cox CE and Khakpour N: Factors associated with improved outcome after surgery in metastatic breast cancer patients. Am J Surg 198: 511-515, 2009.

4. Munhoz AM, Montag E, Filassi JR and Gemperli R: Current approaches to managing partial breast defects: The role of conservative breast surgery reconstruction. Anticancer Res 34: 1099-1114, 2014.

5. Longaker MT, Aston SJ, Baker DC and Rohrich RJ: Fat Transfer in 2014: What we do not know. Plast Reconstr Surg 133: 1305-1307, 2014

6. Eto H, Kato H, Suga H, Aoi N, Doi K, Kuno S and Yoshimura K: The Fate of Adipocytes after nonvascularized fat grafting. Plast Reconstr Surg 129: 1081-1092, 2012.

7. Chung MT, Paik KJ, Atashroo DA, Hyun JS, McArdle A, Senarath-Yapa K, Zielins ER, Tevlin R, Duldulao C, Hu MS, et al: Studies in fat grafting: Part I. Effects of injection technique on in vitro fat viability and in vivo volume retention. Plast Reconstr Surg 134: 29-38, 2014.

8. Atashroo D, Raphel J, Chung MT, Paik KJ, Parisi-Amon A, McArdle A, Senarath-Yapa K, Zielins ER, Tevlin R, Duldulao C, et al: Studies in fat grafting: Part II. Effects of injection mechanics on material properties of fat. Plast Reconstr Surg 134: 39-46, 2014.

9. Dong Z, Peng Z, Chang Q, Zhan W, Zeng Z, Zhang S and Lu F: The angiogenic and adipogenic modes of adipose tissue after free fat grafting. Plast Reconstr Surg 135: 556e-567e, 2015.

10. Bellei B, Migliano E, Tedesco M, Caputo S, Papaccio F, Lopez G and Picardo $\mathrm{M}$ : Adipose tissue-derived extracellular fraction characterization: Biological and clinical considerations in regenerative medicine. Stem Cell Res Ther 9: 207, 2018.
11. Yoshimura K, Shigeura T, Matsumoto D, Sato T, Takaki Y, Aiba-Kojima E, Sato K, Inoue K, Nagase T, Koshima I, et al: Characterization of freshly isolated and cultured cells derived from the fatty and fluid portions of liposuction aspirates. J Cell Physiol 208: 64-76, 2006.

12. Pearl RA, Leedham SJ and Pacifico MD: The safety of autologous fat transfer in breast cancer: Lessons from stem cell biology. J Plast Reconstr Aesthet Surg 65: 283-288, 2012.

13. Wang Y, Lehuédé C, Laurent V, Dirat B, Dauvillier S, Bochet L, Le Gonidec S, Escourrou G, Valet P and Muller C: Adipose tissue and breast epithelial cells: A dangerous dynamic duo in breast cancer. Cancer Lett 324: 142-151, 2012.

14. Kolle SF, Fischer-Nielsen A, Mathiasen AB, Elberg JJ, Oliveri RS, Glovinski PV, Kastrup J, Kirchhoff M, Rasmussen BS, Talman ML, et al: Enrichment of autologous fat grafts with ex-vivo expanded adipose tissue-derived stem cells for graft survival: A randomised placebo-controlled trial. Lancet 382: 1113-1120, 2013.

15. Doi K, Ogata F, Eto $H$, Kato $H$, Kuno $S$, Kinoshita K, Kanayama K, Feng J, Manabe I and Yoshimura K: Differential contributions of graft-derived and host-derived cells in tissue regeneration/remodeling after fat grafting. Plast Reconstr Surg 135: 1607-1617, 2015.

16. Suga H, Eto H, Aoi N, Kato H, Araki J, Doi K, Higashino T and Yoshimura K: Adipose tissue remodeling under ischemia: Death of adipocytes and activation of stem/progenitor cells. Plast Reconstr Surg 126: 1911-1923, 2010.

17. Kuhbier JW, Bucan V, Reimers K, Strauss S, Lazaridis A, Jahn S, Radtke C and Vogt PM: Observed changes in the morphology and phenotype of breast cancer cells in direct co-culture with adipose-derived stem cells. Plast Reconstr Surg 134: 414-423, 2014.

18. Kamat P, Schweizer R, Kaenel P, Salemi S, Calcagni M, Giovanoli P, Gorantla VS, Eberli D, Andres AC and Plock JA: Human adipose-derived mesenchymal stromal cells may promote breast cancer progression and metastatic spread. Plast Reconstr Surg 136: 76-84, 2015.

19. Kucerova L, Skolekova S, Matuskova M, Bohac M and Kozovska Z: Altered features and increased chemosensitivity of human breast cancer cells mediated by adipose tissue-derived mesenchymal stromal cells. Bmc Cancer 13: 535, 2013.

20. Zhang Y, Daquinag A, Traktuev DO, Amaya-Manzanares F Simmons PJ, March KL, Pasqualini R, Arap W and Kolonin MG: White adipose tissue cells are recruited by experimental tumors and promote cancer progression in mouse models. Cancer Res 69: 5259-5266, 2009.

21. Eterno V, Zambelli A, Pavesi L, Villani L, Zanini V, Petrolo G, Manera S, Tuscano A and Amato A: Adipose-derived mesenchymal stem cells (ASCs) may favour breast cancer recurrence via HGF/c-Met signaling. Oncotarget 5: 613-633, 2014.

22. Alessio N, Bohn W, Rauchberger V, Rizzolio F, Cipollaro M, Rosemann M, Irmler M, Beckers J, Giordano A and Galderisi U: Silencing of RB1 but not of RB2/P130 induces cellular senescence and impairs the differentiation potential of human mesenchymal stem cells. Cell Mol Life Sci 70: 1637-1651, 2013.

23. Gary RK and Kindell SM: Quantitative assay of senescence-associated beta-galactosidase activity in mammalian cell extracts. Anal Biochem 343: 329-334, 2005.

24. Livak KJ and Schmittgen TD: Analysis of relative gene expression data using real-time quantitative PCR and the $2^{-\Delta \Delta C_{\mathrm{T}}}$ method. Methods 25: 402-408, 2001.

25. Wang W, Zhong W, Yuan J, Yan C, Hu S, Tong Y, Mao Y, Hu T, Zhang $B$ and Song $G$ : Involvement of Wnt/ $\beta$-catenin signaling in the mesenchymal stem cells promote metastatic growth and chemoresistance of cholangiocarcinoma. Oncotarget 6: 42276-42289, 2015.

26. Zhou M, Liu S, Jiang Y, Ma H, Shi M, Wang Q, Zhong W, Liao W and Xing MM: Doxorubicin-loaded single wall nanotube thermo-sensitive hydrogel for gastric cancer chemo-photothermal therapy. Adv Funct Mater 25: 4730-4739, 2015.

27. Naito S, von Eschenbach AC, Giavazzi R and Fidler IJ: Growth and metastasis of tumor cells isolated from a human renal cell carcinoma implanted into different organs of nude mice. Cancer Res 46: 4109-4115, 1986.

28. Choi JS, Kim BS, Kim JY, Kim JD, Choi YC, Yang HJ, Park K, Lee HY and Cho YW: Decellularized extracellular matrix derived from human adipose tissue as a potential scaffold for allograft tissue engineering. J Biomed Mater Res A 97: 292-299, 2011.

29. Rhee K, Lee J and Eom Y: Mesenchymal stem cell-mediated effects of tumor support or suppression. Int J Mol Sci 16: 30015-30033, 2015. 
30. Waked K, Colle J, Doornaert M, Cocquyt V and Blondeel P. Systematic review: The oncological safety of adipose fat transfer after breast cancer surgery. Breast 31: 128-136, 2017.

31. Massa M, Gasparini S, Baldelli I, Scarabelli L, Santi P, Quarto R and Repaci E: Interaction between breast cancer cells and adipose tissue cells derived from fat grafting. Aesthet Surg J 36: 358-363, 2016.

32. Ito S, Kai Y, Masuda T, Tanaka F, Matsumoto T, Kamohara Y, Hayakawa $\mathrm{H}$, Ueo $\mathrm{H}$, Iwaguro $\mathrm{H}$, Hedrick $\mathrm{MH}$, et al: Long-term outcome of adipose-derived regenerative cell-enriched autologous fat transplantation for reconstruction after breast-conserving surgery for Japanese women with breast cancer. Surg Today 47: 1500-1511, 2017.

33. Bielli A, Scioli MG, Gentile P, Agostinelli S, Tarquini C, Cervelli V and Orlandi A: Adult adipose-derived stem cells and breast cancer: A controversial relationship. Springerplus 3: 1-10, 2014.

34. Ponte AL, Marais E, Gallay N, Langonne A, Delorme B, Herault $\mathrm{O}$, Charbord $\mathrm{P}$ and Domenech $\mathrm{J}$ : The in vitro migration capacity of human bone marrow mesenchymal stem cells: Comparison of chemokine and growth factor chemotactic activities. Stem Cells 25: 1737-1745, 2007.

35. Spaeth E, Klopp A, Dembinski J, Andreeff M and Marini F: Inflammation and tumor microenvironments: Defining the migratory itinerary of mesenchymal stem cells. Gene Ther 15 : $730-738,2008$

36. Lejmi E, Perriraz N, Clément S, Morel P, Baertschiger R, Christofilopoulos P, Meier R, Bosco D, Bühler LH and Gonelle-Gispert C: Inflammatory chemokines MIP-18 and MIP-3 $\alpha$ are involved in the migration of multipotent mesenchymal stromal cells induced by hepatoma cells. Stem Cells Dev 24: 1223-1235, 2015.

37. Chamberlain G, Smith H, Rainger GE and Middleton $\mathbf{J}$ : Mesenchymal stem cells exhibit firm adhesion, crawling, spreading and transmigration across aortic endothelial cells: Effects of chemokines and shear. PLoS One 6: e25663, 2011.

38. Wang H, Cao F, De A, Cao Y, Contag C, Gambhir SS, Wu JC and Chen X: Trafficking mesenchymal stem cell engraftment and differentiation in tumor-bearing mice by bioluminescence imaging. Stem Cells 27: 1548-1558, 2009.

39. Menon LG, Picinich S, Koneru R, Gao H, Lin SY, Koneru M, Mayer-Kuckuk P, Glod J and Banerjee D: Differential gene expression associated with migration of mesenchymal stem cells to conditioned medium from tumor cells or bone marrow cells. Stem Cells 25: 520-528, 2007.

40. Ho IA, Chan KY, Ng WH, Guo CM, Hui KM, Cheang P and Lam PY: Matrix metalloproteinase 1 is necessary for the migration of human bone marrow-derived mesenchymal stem cells toward human glioma. Stem Cells 27: 1366-1375, 2009.

41. Egea V, von Baumgarten L, Schichor C, Berninger B, Popp T, Neth P, Goldbrunner R, Kienast Y, Winkler F, Jochum M, et al TNF- $\alpha$ respecifies human mesenchymal stem cells to a neural fate and promotes migration toward experimental glioma. Cell Death Differ 18: 853-863, 2011.

42. Dwyer RM, Potter-Beirne SM, Harrington KA, Lowery AJ, Hennessy E, Murphy JM, Barry FP, O'Brien T and Kerin MJ: Monocyte chemotactic protein-1 secreted by primary breast tumors stimulates migration of mesenchymal stem cells. Clin Cancer Res 13: 5020-5027, 2007.

43. Lazennec G and Richmond A: Chemokines and chemokine receptors: New insights into cancer-related inflammation. Trends Mol Med 16: 133-144, 2010.

44. Balkwill F: Cancer and the chemokine network. Nat Rev Cancer 4: 540-550, 2004.

45. Zernecke A, Weber KS, Erwig LP, Kluth DC, Schroppel B, Rees AJ and Weber C: Combinatorial model of chemokine involvement in glomerular monocyte recruitment: Role of CXC chemokine receptor 2 in infiltration during nephrotoxic nephritis. J Immunol 166: 5755-5762, 2001.

46. Ali S and Lazennec G: Chemokines: Novel targets for breast cancer metastasis. Cancer Metastasis Rev 26: 401-420, 2007.

47. Zlotnik A, Burkhardt AM and Homey B: Homeostatic chemokine receptors and organ-specific metastasis. Nat Rev Immunol 11: 597-606, 2011.
48. Escobar P, Bouclier C, Serret J, Bieche I, Brigitte M, Caicedo A, Sanchez E, Vacher S, Vignais ML, Bourin P, et al: IL-1 $\beta$ produced by aggressive breast cancer cells is one of the factors that dictate their interactions with mesenchymal stem cells through chemokine production. Oncotarget 6: 29034-29047, 2015.

49. Griffith JW, Sokol CL and Luster AD: Chemokines and chemokine receptors: Positioning cells for host defense and immunity. Annu Rev Immunol 32: 659-702, 2014.

50. Li Y, Wu J, Zhang W, Zhang $\mathrm{N}$ and Guo $\mathrm{H}$ : Identification of serum CCL15 in hepatocellular carcinoma. Br J Cancer 108: 99-106, 2013

51. Cao L, Zhou Y, Zhai B, Liao J, Xu W, Zhang R, Li J, Zhang Y, Chen L, Qian H, et al: Sphere-forming cell subpopulations with cancer stem cell properties in human hepatoma cell lines. BMC Gastroenterol 11: 71, 2011.

52. Weiswald L, Bellet D and Dangles-Marie V: Spherical cancer models in tumor biology. Neoplasia 17: 1-15, 2015.

53. Pastrana E, Silva-Vargas V and Doetsch F: Eyes wide open: A critical review of sphere-formation as an assay for stem cells. Cell Stem Cell 8: 486-498, 2011.

54. Ponti D, Costa A, Zaffaroni N, Pratesi G, Petrangolini G, Coradini D, Pilotti S, Pierotti MA and Daidone MG: Isolation and in vitro propagation of tumorigenic breast cancer cells with stem/progenitor cell properties. Cancer Res 65: 5506-5511, 2005.

55. Liu A, Yu X and Liu S: Pluripotency transcription factors and cancer stem cells: Small genes make a big difference. Chin J Cancer 32: 483-487, 2013.

56. Santini R, Pietrobono S, Pandolfi S, Montagnani V, D'Amico M, Penachioni JY, Vinci MC, Borgognoni L and Stecca B: SOX2 regulates self-renewal and tumorigenicity of human melanoma-initiating cells. Oncogene 33: 4697-4708, 2014.

57. Turhan AG, Lemoine FM, Debert C, Bonnet ML, Baillou C, Picard F, Macintyre EA and Varet B: Highly purified primitive hematopoietic stem cells are PML-RARA negative and generate nonclonal progenitors in acute promyelocytic leukemia. Blood 85: 2154-2161, 1995.

58. Holyoake TL, Jiang X, Drummond MW, Eaves AC and Eaves CJ: Elucidating critical mechanisms of deregulated stem cell turnover in the chronic phase of chronic myeloid leukemia. Leukemia 16: 549-558, 2002.

59. Marsden CG, Wright MJ, Pochampally R and Rowan BG: Breast tumor-initiating cells isolated from patient core biopsies for study of hormone action. Methods Mol Biol 590: 363-375, 2009.

60. Ricci-Vitiani L, Lombardi DG, Pilozzi E, Biffoni M, Todaro M, Peschle C and De Maria R: Identification and expansion of human colon-cancer-initiating cells. Nature 445: 111-115, 2007.

61. Mani SA, Guo W, Liao MJ, Eaton EN, Ayyanan A, Zhou AY, Brooks M, Reinhard F, Zhang CC, Shipitsin M, et al: The epithelial-mesenchymal transition generates cells with properties of stem cells. Cell 133: 704-715, 2008.

62. Thiery JP and Sleeman JP: Complex networks orchestrate epithelial-mesenchymal transitions. Nat Rev Mol Cell Biol 7: 131-142, 2006.

63. Kalluri R and Weinberg RA: The basics of epithelialmesenchymal transition. J Clin Invest 119: 1420-1428, 2009.

64. Vega SL, Kwon MY and Burdick JA: Recent advances in hydrogels for cartilage tissue engineering. Eur Cell Mater 33: 59-75, 2017.

65. Kondiah PJ, Choonara YE, Kondiah PP, Marimuthu T, Kumar P, du Toit LC and Pillay V: A review of injectable polymeric hydrogel systems for application in bone tissue engineering. Molecules 21: pii: E1580, 2016.

66. Zuk PA, Zhu M, Mizuno H, Huang J, Futrell JW, Katz AJ, Benhaim P, Lorenz HP and Hedrick MH: Multilineage cells from human adipose tissue: Implications for cell-based therapies. Tissue Eng 7: 211-228, 2001.

This work is licensed under a Creative Commons Attribution-NonCommercial-NoDerivatives 4.0 International (CC BY-NC-ND 4.0) License. 